\title{
An uncommon case of hydropneumothorax and haemoptysis
}

\author{
Sharon Coral Sturney, Jeffrey Meecham-Jones, Andrew White
}

Department of Respiratory Medicine, Gloucestershire Royal Hospital, Gloucester, UK

\section{Correspondence to} Dr Sharon Coral Sturney, sharonsturney@doctors.org.uk

\section{DESCRIPTION}

A 37-year-old woman presented to the chest clinic with catamenial bilateral lower chest pain, minor haemoptysis and epistaxis. She had a longstanding history of endometriosis, including previous resection of an umbilical deposit. She had been taking progesterone tablets until a few months prior to the presentation.

The chest radiograph showed a left-sided hydropneumothorax. A CT scan showed bilateral hydropneumothoraces, larger on the left, with bilateral pleural endometrial deposits (figure 1A), including a large deposit on the right hemidiaphragm (figure 1B). Pulmonary endometrial deposits can be seen as well-demarcated subpleural ovoid masses or
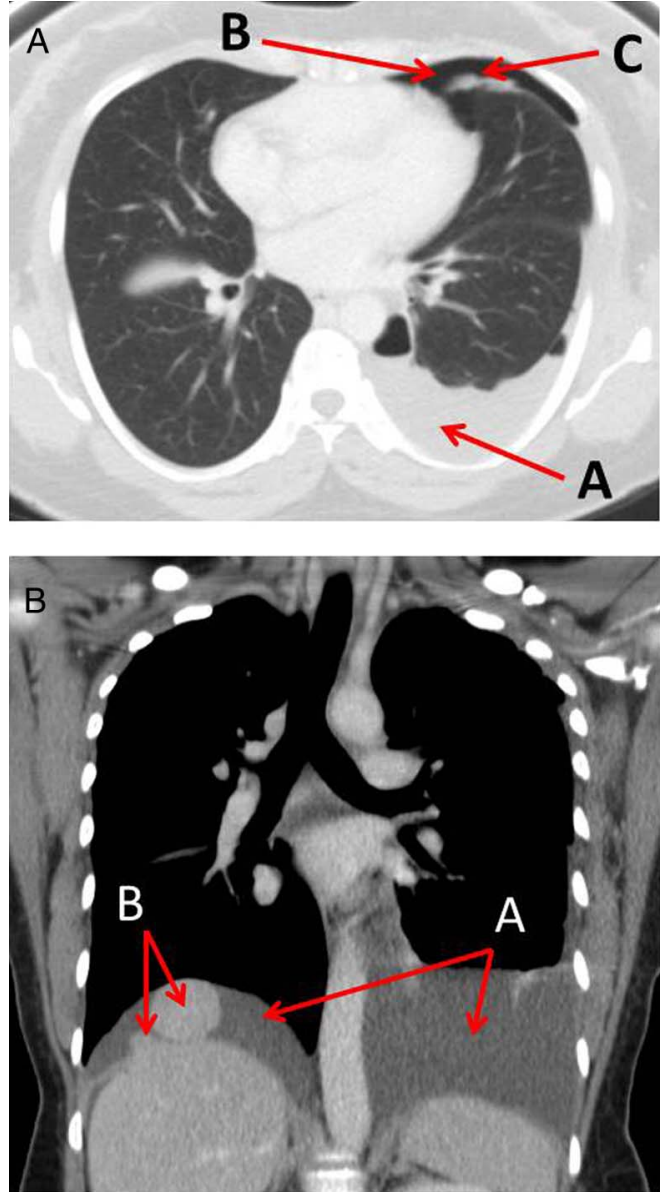

Figure 1 (A) Axial CT image showing a left-sided hydropneumothorax (pleural effusion marked $A$, air marked $B$ and pleural endometrial deposits anteriorly marked C). (B) Coronal CT image showing bilateral pleural effusions (marked A) and two large deposits of endometrial tissue on the right hemidiaphragm (marked B). ground glass opacities, changing in size during the menstrual cycle. ${ }^{1}$ The effusion was aspirated revealing a heavily blood stained exudate with no microbiological growth and no malignant cells on cytological examination. A T-spot test was negative.

The diagnosis of thoracic endometriosis syndrome is based on clinical features (chest pain, dyspnoea and haemoptysis) associated with menstruation and radiological findings of pneumothorax, pleural effusion, nodules, thin-walled cavities and bullae. ${ }^{2}$ The haemopneumothorax resolved within 3 months without treatment as she was keen on having another child.

This is an unusual case of thoracic endometriosis, as all other reported cases have involved either pneumothorax, haemothorax or haemoptysis separately but not together. ${ }^{2}$ It highlights the need to consider thoracic endometriosis syndrome in women of childbearing age who present with cyclical chest symptoms and signs, especially if they already have a diagnosis of endometriosis.

\section{Learning points}

- Endometriosis affects $5-15 \%$ of women of childbearing age, ${ }^{3}$ however, despite the chest being the most common extrapelvic site for endometrial deposits, thoracic endometriosis syndrome is rare. ${ }^{2}$

- The exact pathogenesis of thoracic endometriosis is unclear; retrograde menstruation with transfer of endometrial tissue across the diaphragm is a postulated theory. ${ }^{2}$

- Treatment options include oral contraceptives, gonadotropin-releasing hormone analogues or resection of the ovaries. Thoracic surgical modalities, for example thorascopic pleurodesis, can be used if the woman wants to become pregnant, however recurrence is common, especially if multiple endometrial deposits are present. ${ }^{2}$

Contributors SCS, JM-J and AW were involved in the patient's case. SCS drafted the article and all the authors were involved in the article revision and agreed to the final version.

Competing interests None.

Patient consent Obtained.

Provenance and peer review Not commissioned; externally pee reviewed. 


\section{REFERENCES}

1 Chung SY, Kim SJ, Kim TH, et al. Computed tomography findings of pathologically confirmed pulmonary parenchymal endometriosis. J Comput Assist Tomogr 2005;29:815-18.
2 Augoulea A, Lambrinoudaki I, Christodoulakos G. Thoracic endometriosis syndrome. Respiration 2008;75:113-19.

3 Giudice LC, Kao LC. Endometriosis. Lancet 2004;364:1789-99.

Copyright 2013 BMJ Publishing Group. All rights reserved. For permission to reuse any of this content visit

http://group.bmj.com/group/rights-licensing/permissions.

BMJ Case Report Fellows may re-use this article for personal use and teaching without any further permission.

Become a Fellow of BMJ Case Reports today and you can:

- Submit as many cases as you like

- Enjoy fast sympathetic peer review and rapid publication of accepted articles

- Access all the published articles

- Re-use any of the published material for personal use and teaching without further permission

For information on Institutional Fellowships contact consortiasales@bmjgroup.com

Visit casereports.bmj.com for more articles like this and to become a Fellow 